

\section{TENNESSEE VALLEY AUTHORITY}

Environmental Research Center

EVALUATION OF TVA'S MODEL SITE AND

INDIVIDUAL TECHNOLOGY POLLUTION PREVENTION

DEMONSTRATION PROGRAMS AND THEIR IMPACT

ON THE AGRICHEMICAL INDUSTRY

\section{By}

G. Scott Simpson

Agricultural Economist

Agricultural Research and Practices

Muscle Shoals, Alabama

June 1995 


\section{DISCLAIMER}

Portions of this document may be illegible in electronic image products. Images are produced from the best available original document. 


\section{DISCLAIMER}

This report was prepared as an account of work sponsored by an agency of the United States Government. Neither the United States Government nor any agency thereof, nor any of their employees, make any warranty, express or implied, or assumes any legal liability or responsibility for the accuracy, completeness, or usefulness of any information, apparatus, product, or process disclosed, or represents that its use would not infringe privately owned rights. Reference herein to any specific commercial product, process, or service by trade name, trademark, manufacturer, or otherwise does not necessarily constitute or imply its endorsement, recommendation, or favoring by the United States Government or any agency thereof. The views and opinions of authors expressed herein do not necessarily state or reflect those of the United States Government or any agency thereof. 


\section{CONTENTS}

Page

Introduction $\ldots \ldots \ldots \ldots \ldots \ldots \ldots \ldots \ldots \ldots \ldots \ldots \ldots \ldots \ldots$

Pollution Prevention Programs at TVA . . . . . . . . . . . . . . 2

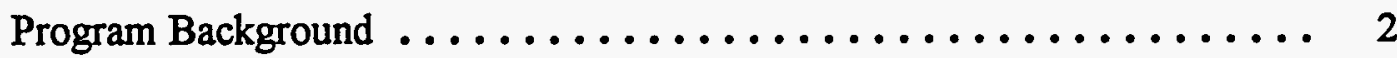

Program Philosophy and Objectives .................. 2

Model Site Demonstrations and Individual

Technology Demonstrations. . . . . . . . . . . . . . . 3

Pollution Prevention Research and Application $\ldots \ldots \ldots \ldots \ldots \ldots \ldots, 6$

Program Influence on State Containment Regulations $\ldots \ldots \ldots \ldots \ldots \ldots 8$

Program Influence on TVA . . . . . . . . . . . . . . . . 10

Impact of Pollution Prevention Technology

Adoption on the Agrichemical Retailer . . . . . . . . . . . . . . . 11

Technology Evaluation and TVA Performance $\ldots \ldots \ldots \ldots \ldots \ldots \ldots 11$

Economic Costs Associated With Investments

in Pollution Prevention Structures and

Environmental Regulations ..................... 12

Demonstrator Characteristics and the Annual

Cost of Fertilizer and Chemical Operations ............ 12

Investment in Pollution Prevention Structures . . . . . . . . . 16

Materials of Construction Cost ................ 16

Annual Cost of Pollution Prevention

Structures/Environmental Regulations .............. 19

Estimation of Annual Environmental

Costs Using an Economic Engineering Approach . . . . . . . 21

Dealer Strategies for Offsetting the Cost of Pollution

Prevention Structures/Environmental Regulations . . . . . . . . 23 


\section{CONTENTS}

(Continued)

Benefits Accrued From Installation of

Pollution Prevention Structures . . . . . . . . . . . . . . . . . . . . . . 24

Tangible Benefits . . . . . . . . . . . . . . . . . . . . . . 24

Intangible Benefits . . . . . . . . . . . . . . . . . . . . . . 24

Technology Transfer Aspects of the MSD/ITD Programs . . . . . . . . . . . . . 25

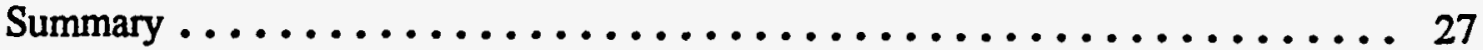

Sources of Information . . . . . . . . . . . . . . . . . . . . . . . . 29

Acknowledgments ................................ 30

Participating Demonstrators ......................... 31

Appendixes................................ 32

A. Model Site Demonstrations in the United States. . . . . . . . . . . . 33

B. Individual Technology Demonstrations in the

United States . . . . . . . . . . . . . . . . . . . . . . . . 34

C. Other Pollution Prevention Technology Transfer

Sites in the United States . . . . . . . . . . . . . . . . . . . 35

D. Annual Tonnage Sold by Type of Product at

Demonstration Sites . . . . . . . . . . . . . . . . . . . . 36

E. Estimated Annual Cost of Pollution Prevention

Structures/Environmental Regulations at TVA

Model Site and Individual Technology Demonstrations . . . . . . . . . 37

F. Estimated Annual Fixed and Variable Costs Associated

With Alternative Levels of Investment in Environmental

Facilities and Equipment 


\section{EVALUATION OF TVA'S MODEL SITE AND \\ INDIVIDUAL TECHNOLOGY POLLUTION PREVENTION \\ DEMONSTRATION PROGRAMS AND THEIR IMPACT \\ ON THE AGRICHEMICAL INDUSTRY}

\section{INTRODUCTION}

About 12,000 retail fertilizer dealers distributed over 50 million tons of fertilizer materials in 1994 (TVA Commercial Fertilizers 1994). These same dealers also distribute a large percentage of all pesticides used in the United States, with pesticide consumption exceeding 500 million pounds of active ingredients in 1994 (USDA, 1994). Both fertilizers and pesticides are primary sources of surface and groundwater contamination in the United States.

The high volume of fertilizer and pesticides funneled through a relatively small number of distribution outlets has made these agribusiness sites potential sources of surface/ groundwater contamination in watersheds surrounding the agrichemical facilities. Pollutants can leave the retail sites in a number of ways, with the most common being runoff of spilled materials due to poor stewardship and/or operating practices, onsite washing of tanks and applicators without some method of collecting rinsates, or the more catastrophic occurrence of the rupture of a liquid fertilizer/bulk chemical tank.

The agrichemical industry came under increased pressures in the mid-1980s to implement environmentally sound management practices and to install containment structures around fertilizer and chemical storage/handling areas to prevent future contamination of existing sites or the movement of contaminants offsite. TVA's long and successful history of technology transfer to the retail fertilizer industry, as well as the technical expertise of the Agency's staff, made TVA ideally suited to handle the new environmental challenge. It was during this time period that TVA's Model Site Demonstration Program (MSD) and Individual Technology Demonstration Program (ITD) were conceived. The main objective was and is pollution prevention.

Since inception, the pollution prevention program and the technologies advanced by it have made a very positive impact on the U.S. agrichemical industry, as well as on other TVA programs. This paper is an attempt to document these impacts, with primary focus being placed on the program's impact on the agribusiness dealer who implements the pollution prevention technologies/practices recommended by TVA.

To document the program impact at the agribusiness dealer level, a comprehensive questionnaire was sent to all MSD/ITD cooperators as well as to about 50 fertilizer dealers to whom TVA has provided some form of environmental assistance without benefit of formalized contracts. The questionnaire was designed to collect data on: (1) how well the pollution prevention technologies recommended by TVA actually worked, (2) TVA's performance as a supplier of environmental information, (3) the initial 
investment and annual cost per ton associated with pollution prevention structures installed at the MSD/ITD sites, (4) agribusiness strategies used to offset environmental costs, (5) benefits the agribusinesses accrued as a result of the installation of pollution prevention structures, and (6) the technology transfer aspects of the programs.

\section{POLLUTION PREVENTION PROGRAMS AT TVA}

\section{Program Background}

In the past, the major sanctioning force for TVA agricultural research was TVA's national fertilizer research and development mandate. With the loss of public support for fertilizer research in 1993, TVA restructured its agricultural research program to emphasize development of solutions to water quality problems at a watershed level.

TVA was encouraged by the U.S. Environmental Protection Agency (EPA), the U.S. Department of Agriculture, Office of Technology Assessment, state regulators, industry, and others to keep and/or restructure the ongoing pollution prevention projects involving retailers who market or use fertilizers, pesticides, and other agrichemicals. TVA agreed to do so and continues to incorporate these activities in its research program agenda.

National policy is emphasizing the watershed approach as a key concept in managing nonpoint source pollution (NPS) challenges. Everyone lives and works in a watershed-the area from which water drains into a body of water. According to EPA, agriculture is the leading contributor of pollution to 72 percent of the nation's impaired river miles and half of the impaired lake acres. Contaminated groundwater also contributes to the pollution of streams, lakes, and wetlands. Agricultural retailers play a vital role in watershed protection, both directly and indirectly. They can implement technologies and improved management practices onsite. They also can provide services, counsel, and instruction about safe use of fertilizers and crop protection chemicals to farmers and to other users.

\section{Program Philosophy and Objectives}

Farming and related agricultural industries represent about 20 percent of the economic activity in the nation. TVA's pollution prevention program for agricultural retailers recognizes the need to provide practical and affordable solutions to environmental problems in order to protect the economic base of communities by reconciling business viability with environmental protection. The pollution prevention program is not driven by regulatory compliance issues. However, the industry's need to solve compliance-driven problems has provided TVA an entree into working with retailers and also with the agencies responsible for writing regulations on non-compliance issues. TVA's intent is to develop information and experience to guide others--the retailer, by enhancing a pollution prevention consciousness that goes beyond compliance; and the regulator, by providing 
expert information for drafting environmental principles, laws, regulations, and recommendations.

Other important operational principles include: onsite research and testing to encourage adoption of technologies, new or old, to fit the business situation; selective use of incentives to promote participation by industry firms; inter- and intra-agency coordination; and maintaining effective linkages with suppliers of support services.

The general objective of the program is to provide research, development, and application of pollution prevention technologies and strategies for industries which market or use fertilizers, pesticides, and other agricultural chemicals. Specific objectives are to:

(1) conduct applied research to identify environmentally sound and cost-effective materials of construction and practices for pollution prevention at agrichemical industry sites; (2) conduct case study research on "model sites" to determine effectiveness of structures or practices in place or modifications needed to protect the environment; (3) ensure that recommended alternatives are consistent with current or anticipated regulatory principles, laws, regulations, or recommendations; and (4) provide environmental information on research findings to agricultural industries and to other institutions serving agriculture.

\section{Model Site Demonstrations and Individual}

Technology Demonstrations

Model site demonstrations are joint efforts between TVA, the agrichemical industry, and cooperating organizations, including state fertilizer and chemical associations, state regulatory officials, environmental management firms, and university staff, to improve environmental stewardship of agricultural industries. The demonstration concept used is based on TVA's history of success in utilizing demonstrations as an educational tool. The model site demonstrations and individual technology demonstrations serve as "living laboratories" for researchers, technologists, and educators, as well as participants, on ways for retailers to improve environmental conditions at their sites.

Appendix A and appendix B provide a list of 62 MSD/ITD sites in 27 states that TVA has served over the past several years. The geographic locations of these sites are found in figure 1 on the following page. Appendix $C$ furnishes a partial listing of other agribusiness dealers across the United States to whom TVA has provided some level of environmental assistance. However, these dealerships do not, by definition, qualify as either MSDs or ITDs.

The 19 demonstrations listed in appendix A are termed "model sites" because they emphasize good environmental stewardship for the entire business operation. These sites demonstrate to other dealers how to keep raw materials and products onsite and how to prevent accidental spills from getting into surface or groundwater. These demonstrations stemmed from recognized needs to: (1) develop information and expertise to guide others; (2) test numerous methods of containment, materials of construction, management 
Figure 1

Geographic Locations of Pollution Prevention Research/Demonstrations for Agricultural Retailers

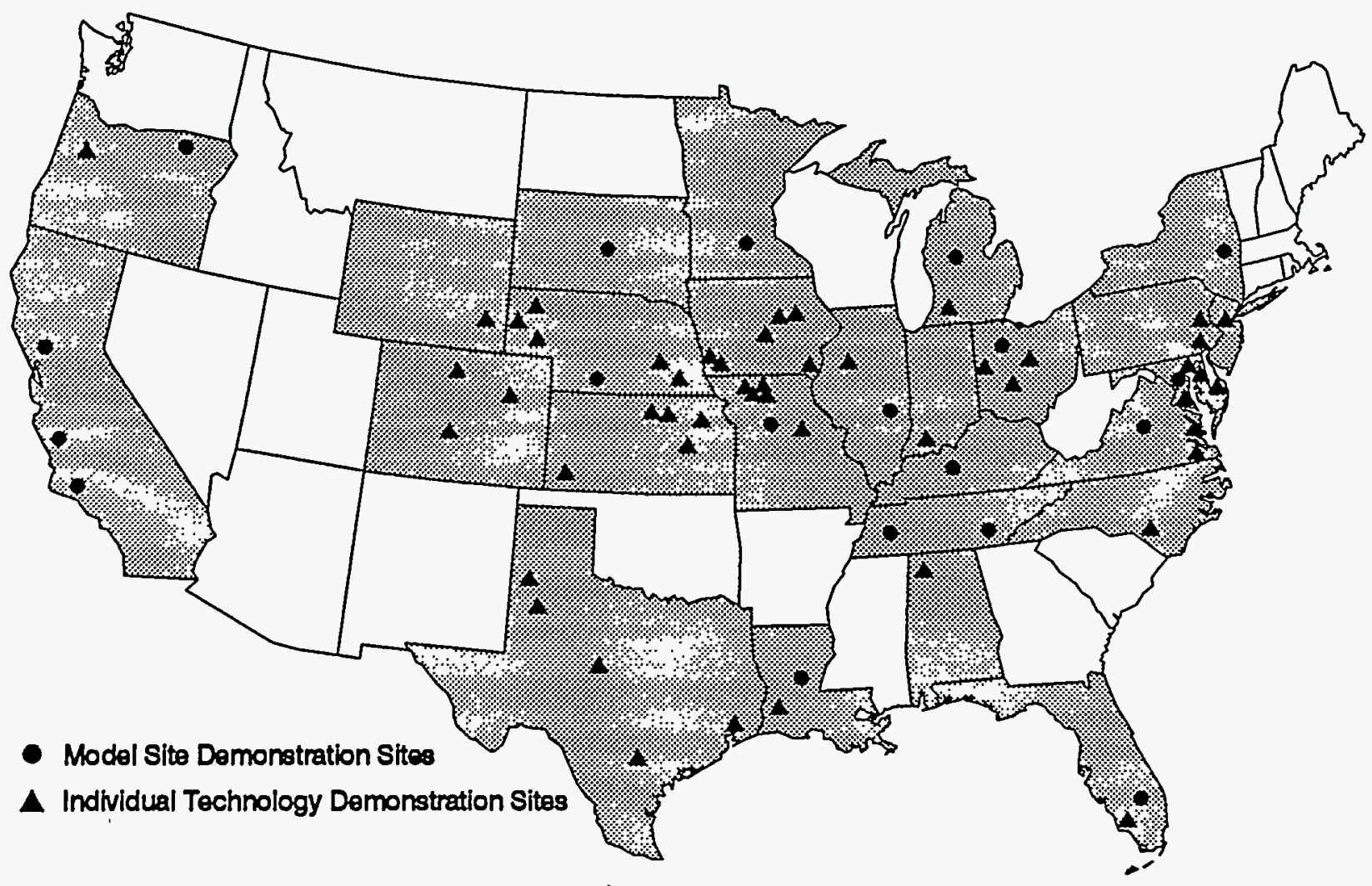


practices, and monitoring techniques for reducing pollutant discharges; (3) enhance/ emphasize industry's commitment to environmental stewardship and its willingness to spend a great amount of money to protect the environment; (4) identify future research needs; and (5) serve as a catalyst to encourage cooperation across a broad spectrum of appropriate industry and agency groups to identify and develop practical solutions that fertilizer dealers could understand and implement.

One drawback to the MSD program has been the time required to select, implement, and showcase a site. To effect the transfer of environmental technologies to more sites at a lower cost to TVA, the concept of the individual technology demonstration was born. ITDs tend to move much faster, cost considerably less to implement, and involve more tangible concepts than do MSDs. And ITDs fit objectives of introducing new environmental technologies or improving attendant systems for operational technologies. Appendix B contains a list of the 43 ITDs completed to date. ITDs are designed to address specific technologies that hold promise for reducing costs while enhancing technical, environmental, and economic efficiencies. These demonstrations may involve aspects as simple as the design of a load pad or as complex as a complete retrofit of an existing site or the design of a new plant at a different location. In effect, ITDs can, and very often do, encompass the "entire site" just as the MSDs do, the only difference being the number of agencies involved in the initial planning and implementation.

Pollution prevention program emphasis is on transferring currently available technology to help solve environmental and waste management problems and on developing and introducing needed new technologies. The MSD/ITD programs attempt to bridge the gap between research findings and their practical application and evaluation by retail dealers under field conditions.

Pollution prevention information generated from demonstration sites is shared with others in a variety of ways, typically falling under the category of "technical assistance and information transfer." Forums for delivery are symposiums, conferences, articles published in trade magazines, TVA publications, technical assistance, open houses and organized tours at demonstration locations, committee representation, video productions, and the TVA Environmental Handbook for Fertilizer and Agrichemical Dealers.

TVA's role in the MSDs has been: (1) site assessment and recommendations, (2) engineering assistance, (3) engineering concept designs, and (4) research and educational forums. Agri-industry's role has included: (1) paying for the installation of recommended environmental features and (2) providing access to the site for research/ demonstration purposes.

TVA's role in the ITDs is virtually the same as in the MSD program, the exception being that engineering and design work is performed on a cost-share basis with the agrichemical dealer paying up to $\$ 4,500$ for these services. The fee is based on the complexity of the pollution prevention structures designed and installed. 
Results from both programs have: (1) been used to write model legislation at both state and national levels; (2) helped reduce product shrinkage; (3) played a major role in obtaining reduced insurance rates for many retailers; (4) perhaps reduced future cleanup costs; (5) reduced the potential for loss due to vandalism; (6) promoted enhanced community and customer perception of the business unit; (7) brought about increased physical productivity at the facilities involved; (8) produced improved employee productivity; and (9) increased the economic value of sites for future sale.

\section{Pollution Prevention Research and Application}

Most of the products or technologies that TVA has introduced into the marketplace in the past have required substantial initial basic research as well as some degree of field level "applied" research to make the products/technologies work in field applications. The MSD/ITD programs are different in that basic research has not been required. TVA already had vast experience in how agrichemical sites were built and operated. And with this expertise came the knowledge of where problems might arise from an environmental perspective. Therefore, the programs required the application of known containment technologies to a new industry. TVA's expertise in the fertilizer and chemical industry made it uniquely qualified to know what containment technologies could be adapted to agrichemical environments.

At the time the MSD program was initiated in the late 1980s, Iowa was the only state which had containment regulations in place. These regulations, among other things, specified where containment was required and how much. Therefore, TVA's initial efforts in designing pollution prevention structures centered on meeting or exceeding the design criteria for fertilizer and pesticide containment in Iowa.

As the MSD/ITD programs expanded across the United States, so did TVA's knowledge base expand. The staff could draw from a wide range of experiences on which materials of construction worked for agrichemical containment and which did not or which concrete additives or coatings reduced corrosion and freeze damage. This knowledge, combined with original knowledge of retail fertilizer production facilities and their operation, gave TVA a decided advantage in the environmental arena--an advantage that most private engineering firms could not and can not match. Not only can TVA make the necessary recommendations for fertilizer and agricultural chemical containment, but TVA also can advise the dealer on how plant layout can be changed to remove bottlenecks and increase plant efficiency to levels previously unattainable.

The design of pollution prevention structures and development of the management practices mentioned above are addressed by TVA staff who work directly with the agrichemical dealer. Much of the information and expertise used comes from actual field experience. However, many aspects of the design for pollution prevention structures and the management practices are mandated in state containment regulations. TVA, as a 
respected leader and friend to the fertilizer industry, has played both an advisory and direct role in the drafting of state containment regulations.

Pollution prevention structures, by definition, are designed to prevent or greatly reduce the possibility of a release of contaminants into the surrounding environment. Typical examples of pollution prevention structures and/or technologies that TVA has recommended for use in agrichemical facilities include:

- Containment for fluid fertilizers and pesticides.

- Containment around liquid material transfer points, such as load or wash pads.

- Containment around dry material transfer points, such as material loading/unloading and mixing areas.

- Facility redesign (when possible) to achieve environmental and production efficiencies.

- Implementation of environmental best management operating practices.

Containment for fluid fertilizers and pesticides usually involves some form of diking. TVA has typically recommended concrete to form these relatively small containment areas. However, economics usually dictate that containment for large tanks, with capacities over 100,000 gallons, be constructed using earthen dikes, synthetic liners, high-clay content soils, or other soils which meet permeability standards.

A load pad is used to contain fluid materials around material transfer points. Load pads are usually made of concrete and are sloped so that spilled liquids will drain into a sump. Materials collected in the sump are then pumped to holding tanks from which they can be recycled into the production process, sold as a lower-analysis mixture, or land applied. The load pad can also be used by the dealer to wash down application vehicles after use; however, TVA recommends that a separate wash pad be installed. TVA has recommended that where possible these pads should be covered to reduce problems associated with stormwater collection and management.

Spillage of dry materials usually occurs near the blending area; between the blending area and dry storage; or at points where the dry materials are transferred into storage by either truck, rail, or barge. Typically, dry materials can be contained with concrete pads at these transfer points. The concrete prohibits movement of the dry materials and also affords easy cleanup.

Once pollution prevention structures are in place, the dealer then must implement management practices to assure that the facility is operated in an environmentally safe manner. A partial listing of issues the agrichemical dealer must now address include: stormwater management, concrete coating recommendations, the recycle of waste materials, disposal of pesticide containers, where and how pesticides are to be mixed, applicator washdown after use, emergency response plans, employee training, employee safety, security, maintenance of pollution prevention structures, general site stewardship, and nutrient management plans in some areas of the United States. Whenever the 
opportunity arises, TVA will advise plant management on physical layout considerations that will maximize both environmental and production efficiencies.

\section{Program Influence on State Containment Regulations}

TVA's earliest influence on state containment regulations resulted from committee work conducted with the Association of American Plant Food Control Officials (AAPFCO). The TVA/AAPFCO committee combined the best parts of the Iowa and Illinois containment regulations and developed a "model regulation" that could be used by other states to draft their own environmental laws. While regulations differ some from state to state, typically there is not that much difference with respect to the major aspects of the design criteria, thanks to the TVAAAPFCO effort.

Another way TVA has influenced containment regulations is through direct contact with agencies charged with writing the regulations. TVA has involved these agencies in the planning and implementation of all MSDs, and at some point the agencies have been briefed on work at the ITDs. They have seen first-hand the pollution prevention structures installed to prevent contaminants from leaving plant sites. And, as "living laboratories," the MSDs and ITDs have demonstrated over time that the pollution prevention technologies implemented do work. TVA also has provided direct input into the writing of regulations in Idaho, South Dakota, and Tennessee.

As of early 1994, 13 states (Illinois, Indiana, Iowa, Kansas, Michigan, Minnesota, Missouri, Nebraska, Ohio, Oklahoma, South Dakota, Wisconsin, and West Virginia) had containment regulations in place, and 7 others (Colorado, Idaho, Kentucky, Louisiana, North Dakota, Tennessee, and Texas) were in the process of drafting legislation. California and Florida have no containment regulations as such, but the agrichemical industry must be in compliance with state water quality standards. About 75 percent of the fertilizer material used in the United States in 1994 was consumed in these 22 states (see figure 2 on following page). 
Figure 2

\section{States With Containment Regulations in Place or in the .Process of Being Drafted, 1994}

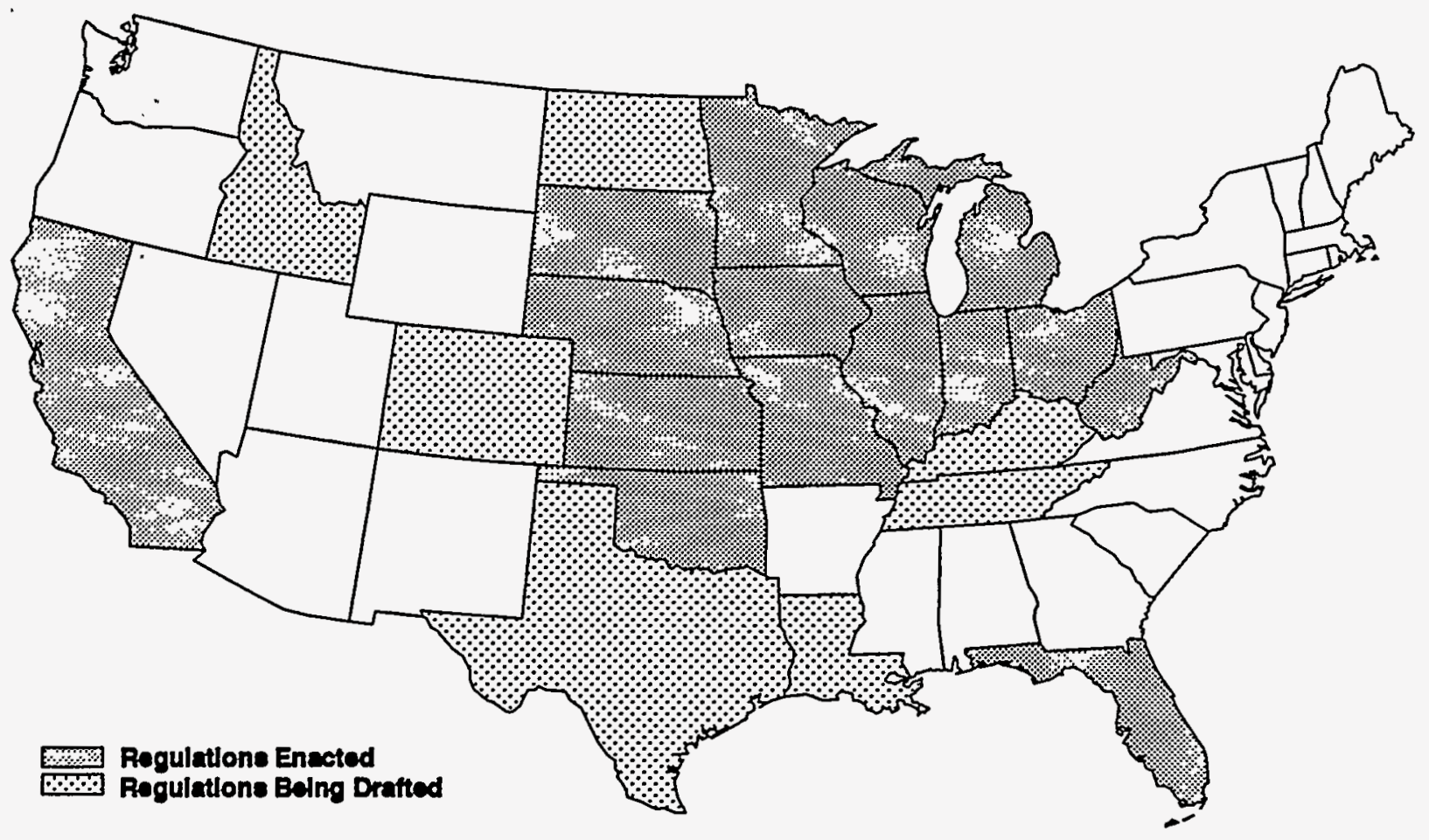




\section{Program Influence on TVA}

Without question, the MSD/ITD programs have enhanced environmental awareness within the agrichemical industry. But TVA and its other programs have benefited as well. TVA, for the past several years, has been an agency transitioning more heavily into the environmental arena, and program success has been a source of visibility for the Center.

The MSD/ITD programs have generated a number of other environmental products/programs that have been highly successful, with some having been copied and utilized by other agencies, such as the Department of Energy and Farmers Home Administration. Some examples of these "spin-offs" are environmental site assessments and the TVA Environmental Handbook for Fertilizer and Agrichemical Dealers. The handbook contains information on: environmental stewardship, environmental management, site assessments, containment, agricultural chemicals, state and federal regulations, SARA Title III, emergency planning, hazardous communication standard, transportation regulations, environmental checklists, information hotlines, TVA and industry contacts, and MSD/ITD brochures. Over 1,200 copies of the handbook have been distributed.

The pollution prevention work performed with the agrichemical industry is now being expanded and applied to other industries that TVA has not worked with in the past. For example, the TVA pollution prevention team is working with the Tennessee Department of Agriculture in designing containment, as well as in writing containment regulations, for structural pest control dealers in that state. The team also is working with the lawn and turf industry, as well as the nursery industry, in designing containment for fertilizers and chemicals stored onsite.

Finally, the technology transfer aspect of the program has been used as a model for technology transfer in other industries. Specifically, the technology transfer activities used by TVA in the past for its fertilizer program, and more recently for its environmental program, encompass: (1) networking with industry groups as well as with state agencies that oversee that industry, (2) developing programs or projects that generate technologies or research information to benefit the entire industry, and (3) demonstrating the new technologies or research results at sites across the state, region, or country. 


\section{IMPACT OF POLLUTION PREVENTION TECHNOLOGY ADOPTION ON THE AGRICHEMICAL RETAILER}

Perhaps the most important indicator of the worth of a technology is if the user is better off after its adoption than before, especially when adoption is mandated rather than voluntary. From an economic perspective, the installation of pollution prevention structures, as well as adherence to other regulatory requirements, such as reporting, carries a real cost to the agrichemical retailer. However, there may also be benefits tied to the adoption of new technology, some tangible and some intangible, that would offset some or all of the additional operating costs accrued as a result of investment in the environmental technology.

TVA developed a questionnaire to document the impact of pollution prevention technologies recommended and implemented at demonstration sites. The survey contained questions relating to how well the pollution prevention technologies work, user satisfaction with TVA as a supplier of technology, the economic cost of the technology, strategies employed by dealers to offset increased costs associated with the investment, the perceived benefits that have accrued to the dealer as a direct result of investment in pollution prevention technology, and, finally, some questions relating to the technology transfer aspects of the demonstrations. Each MSD/ITD dealer, as well as other retailers who have implemented TVA-recommended pollution prevention technologies, was asked to complete the questionnaire. A total of 27 participants responded.

\section{Technology Evaluation and TVA Performance}

Demonstration dealers were asked about the timing of environmental investments, how well the pollution prevention structures recommended by TVA had worked since installation, things they would have done differently, and how well TVA performed as a supplier of environmental information and technology.

Regulatory requirements have now been enacted in most states where demonstration sites are located. However, most of these states gave retailers a grace period between the time when the regulations were enacted and when enforcement was to begin to make necessary environmental changes at their plants. Many of these regulations do not take effect until sometime in 1996-98.

Why then did these demonstration dealers make substantial environmental investments in the early 1990s? Most indicated that their early environmental investment resulted from a combination of needing to make site improvements at older facilities and recognizing that these improvements should be made in such a way that regulatory requirements would be met. Another factor was the knowledge that investments made in pollution prevention structures would significantly lower dealer environmental liabilities. In other words, it was cheaper to prevent an accident than it would be to clean one up. 
The demonstration dealers chose TVA to do the design work primarily because of TVA's experience, expertise, and credibility in the fertilizer industry. These particular dealers were confident that TVA could deliver a containment design that was right for their specific plant as well as one that would be in compliance with all current and future environmental regulations. TVA-designed containment structures also implicitly carried with them a "seal of approval" that could be used as a marketing tool.

All survey respondents indicated that the pollution prevention structures, as designed by TVA, worked to their satisfaction. One demonstrator reported that he liked the design so much that he duplicated it at his other two plants. Only four dealers indicated they would do anything differently if they had the opportunity to do so. The changes they would make were relatively minor and related to the installation of a larger pump for recycle, or stainless steel rings to hold gravel in place around liquid storage tanks, or a different type of waterstop.

About half the respondents pointed out that changes made in the physical layout of their plants to accommodate pollution prevention structures had actually improved traffic flow and streamlined loadout and mixing to the extent that production and application efficiencies were increased. In effect, these dealers increased their daily production which translates into less overtime, greater application efficiencies, and, more importantly, greater production capacity in abbreviated fertilizer seasons.

About a third of the respondents indicated that they believe they could have gotten the same level of environmental engineering expertise from a private engineering firm; however, all respondents stated that they would use TVA again if they had it to do over or if additional structures were required in the future.

\section{Economic Costs Associated With Investments in \\ Pollution Prevention Structures and Environmental Regulations}

\section{Demonstrator Characteristics and the Annual}

\section{Cost of Fertilizer and Chemical Operations}

The demonstrators who responded to the survey typically were large, independent, multiproduct (fluid and dry materials) dealers. Just over half of the respondents were independent dealers, 20 percent were corporately owned, and the remaining 25 percent were cooperatives.

The demonstrators had an average asset value of $\$ 428,000$ in fertilizer-related equipment and $\$ 320,000$ in application equipment, making a total asset value of $\$ 748,000$. The average replacement value of these assets was estimated to be roughly $\$ 1.3$ million. The average age of fertilizer-related equipment was 9.1 years, while age of the application equipment averaged 6.5 years. 
The annual fertilizer tonnage sold by the demonstrators by product type is listed in appendix $\mathrm{D}$ and is shown graphically in figure 3 on the following page. Data represent responses from 18 dealers who reported both tonnage sold and detailed costs associated with their pollution prevention structures. Most of the dealers (16) reported sales of both dry bulk and liquid nitrogen fertilizers. Tonnages of these two materials accounted for 144,771 tons or 64 percent of the total. Suspensions and other fluids accounted for 12 and 13 percent, respectively, of the total, with about half the respondents reporting sales. Ammonia accounted for 8 percent of the total, with 66 percent of the dealers reporting sales. Dry bagged fertilizers accounted for only 2.5 percent of the total, with 9 dealers reporting some tonnage in this product category.

Annual costs for fertilizer and chemical operations were reported by 14 dealers. Total annual cost for the 14 respondents was $\$ 12,373,853$, with 74.9 percent of the total $(\$ 7,269,897)$ being allocated to fertilizer operations and 25.1 percent being allocated to chemical operations. The total tonnage reported by the respondents was 166,153 tons, resulting in an average production cost of $\$ 43.75$ per ton. The median cost of production was $\$ 41.27$ per ton. Figure 4 on page 15 illustrates the estimated annual cost of fertilizer production for the 14 demonstrators reporting. 


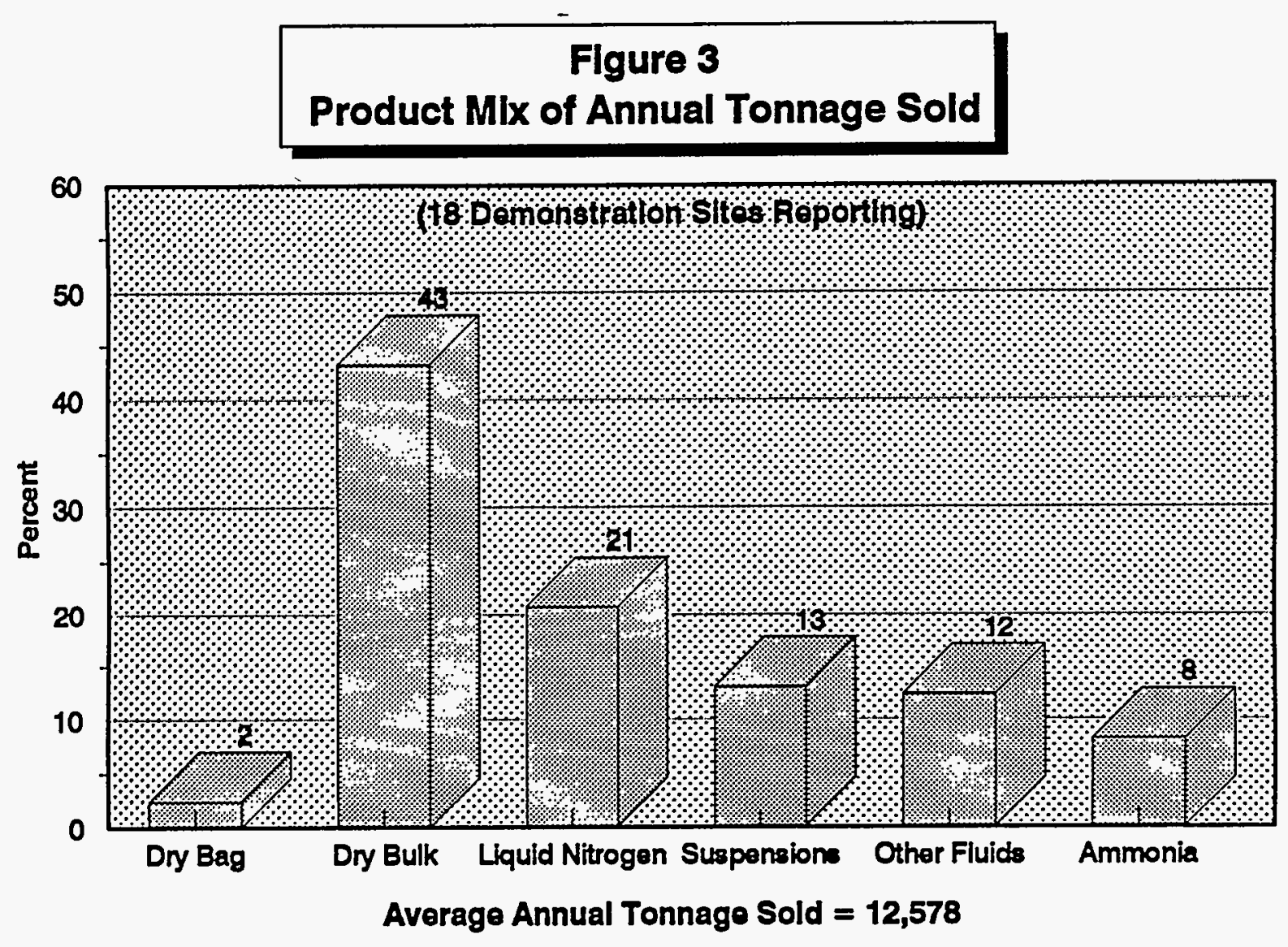




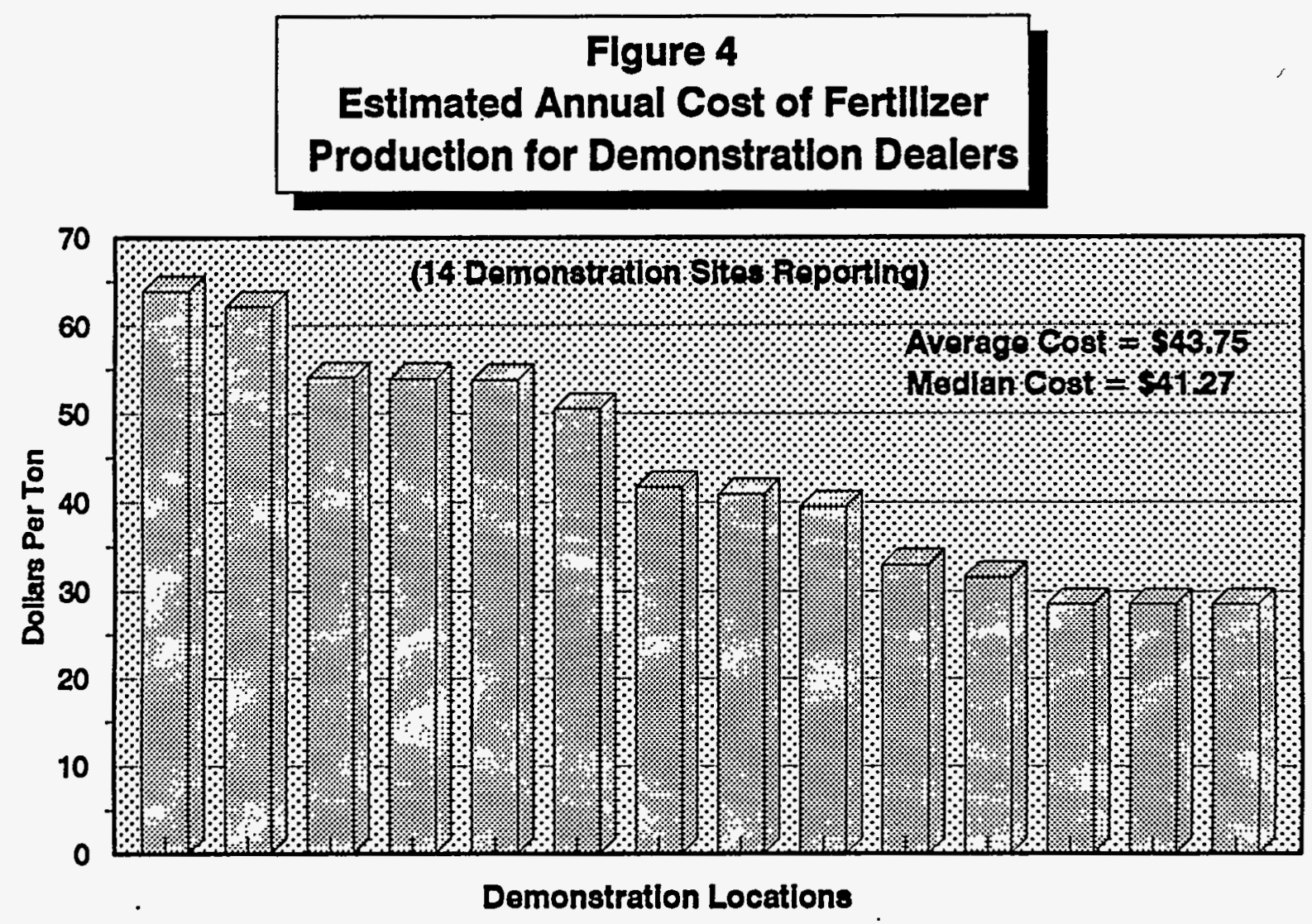




\section{Investment in Pollution Prevention Structures}

Total investment in pollution prevention structures by the 27 demonstrators reporting was $\$ 4,940,070$. Twenty-two respondents indicated that additional expenditures of $\$ 2,204,000$ (total) would be required to bring their facilities into full regulatory compliance. The average current and future investment cost was reported to be $\$ 182,966$ and $\$ 100,182$, respectively. The median current investment was $\$ 100,000$ and the median future investment value was $\$ 45,000$ (see figures 5 and 6 on following pages). The difference between average and median values suggests that the data are substantially skewed to the left, meaning that the median values may be a better indicator of typical investments, current and future, by most agrichemical retailers. About eighty percent of the respondents made noncapital expenditures (e.g., training, etc.) averaging $\$ 13,750$ per location.

Eighty-two percent of the respondents indicated that they used full-time labor in the construction of pollution prevention structures. Utilization of "in-house" labor reduced construction costs by an average of $\$ 23,864$ per location. One dealer reported dollar savings substantially above the $\$ 23,864$ reported above and was therefore omitted from the average.

If it is assumed that the expenditures made by the 27 respondents are representative of the $35 \mathrm{MSD} / \mathrm{ITD}$ dealers who did not return questionnaires, then the total investment at all MSD/ITD locations would be approximately $\$ 16.3$ million, $\$ 11.3$ million in current expenditures and $\$ 5.0$ million in future expenditures.

A linear regression was run to determine if a statistical correlation existed between the size of demonstration, measured by annual tonnage, and environmental expenditures. Results indicated that the correlation coefficient $\left(r^{2}\right)$ was only 0.12 , suggesting very little correlation. The primary reason for the low correlation may be because each and every fertilizer plant is different. Plants differ with respect to current and past management/operating practices, age, and structures already in place that impact environmental investments. Each of these factors will impact the difficulty and the cost that must be incurred to bring a plant into compliance from an environmental standpoint. For example, a relatively new 10,000-ton facility with good management and operating practices in place may require less environmental investment than will a 5,000-ton older facility where past operating practices are environmentally questionable.

\section{Materials of Construction Cost}

Placing a dealer's blender/mixer and loadout under roof is not a regulatory requirement, but it is highly recommended for stormwater management and for related environmental management problems. Nineteen of the demonstrators reported that they have their blenders or mixers under roof. Fifteen of the demonstrators indicated that these buildings 


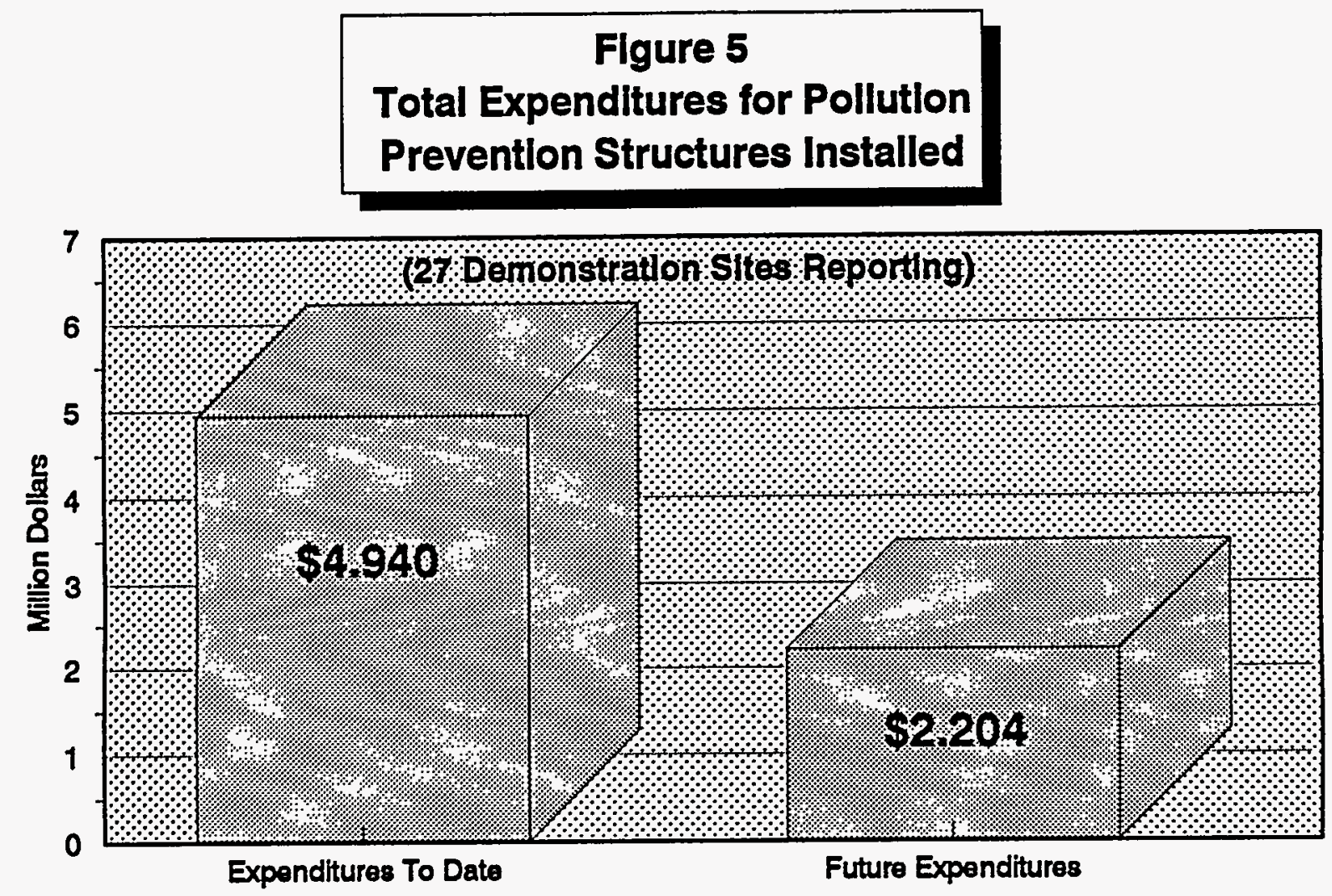




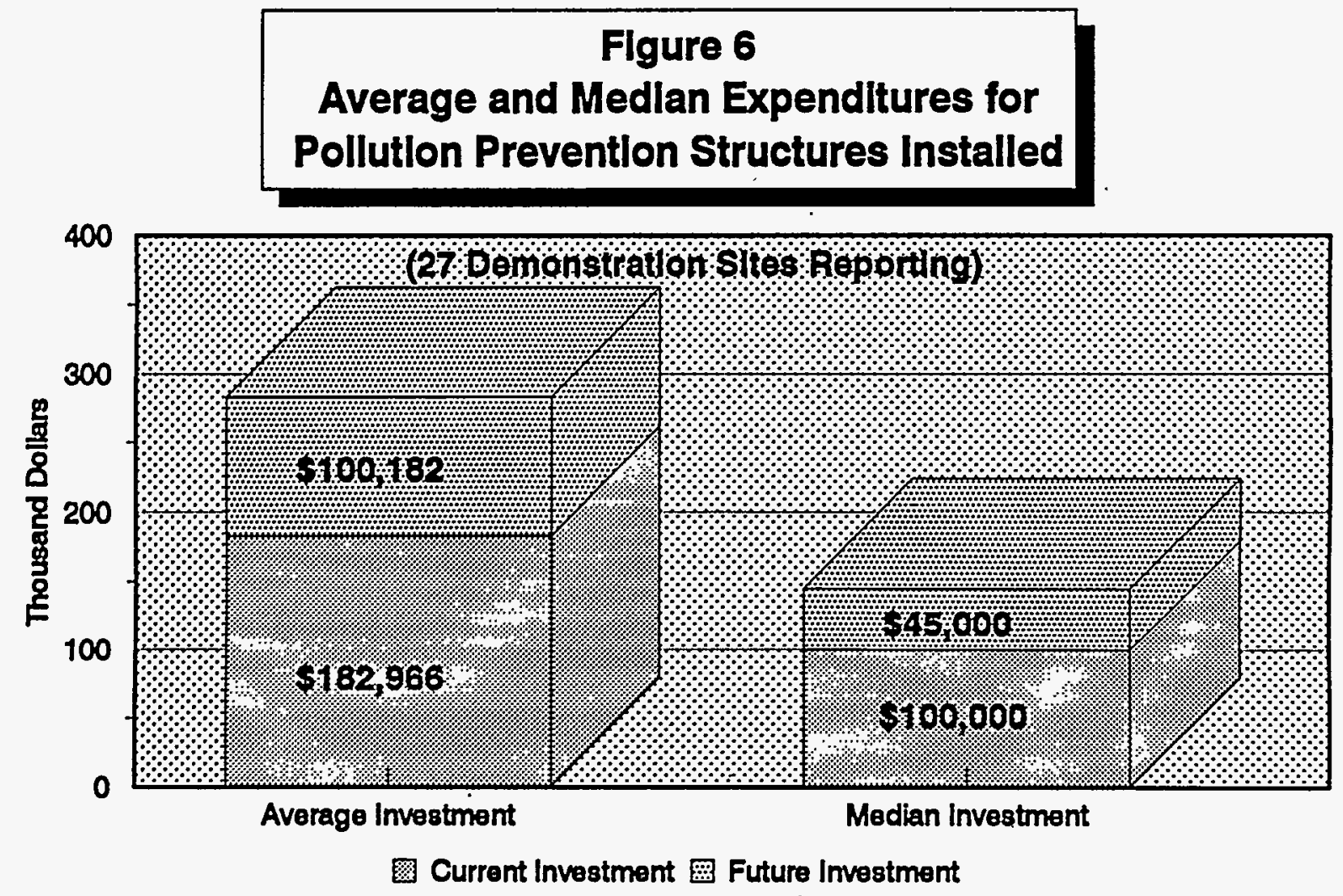


were newly constructed. Average construction cost for these new structures was $\$ 16.13$ per square foot. The range in prices was generally $\$ 12-\$ 22$ per square foot. Construction materials reported were split between wood/siding, wood/steel, and concrete/steel.

Concrete has been the primary material used in the construction of pollution prevention structures at the demonstration sites. The cost of finished concrete, which includes forming, steel placement, concrete placement, and finishing, averaged $\$ 101.22$ per yard and was reported by 18 dealers.

Three dealers provided information on concrete coating costs. These dealers reported average costs of $\$ 0.53$ per square foot. They also indicated that they would have to replace the coating in four years.

Three dealers provided cost information on hypalon synthetic liners. The average cost of the liner was $\$ 2.50$ per square foot.

\section{Annual Cost of Pollution Prevention}

Structures/Environmental Regulations

Data on the annual cost of environmental structures/regulations were collected from 18 demonstration dealers. The annual environmentally related costs were categorized as: (1) salaries and wages, (2) maintenance and repairs, (3) insurance, (4) depreciation, and (5) general office/business/miscellaneous.

The average annual cost of investments in pollution prevention structures and of other items relating to environmental regulations for the 18 demonstrators reporting was $\$ 4.83$ per ton of product sold. This average is based on total costs of $\$ 1,093,280$ and a total annual throughput of 226,408 tons. The median cost per ton was $\$ 4.61$. These data are presented in appendix $\mathrm{E}$ and in figure 7 on the following page.

Salaries and wages allocated as environmental costs include time spent by employees and plant management in: (1) repairing, maintaining, and cleaning pollution prevention structures; (2) preparing environmental reports; and (3) managing any environmentally related matters. The total annual cost of salaries and wages associated with pollution prevention structures and complying with regulations was $\$ 332,988$. This is equal to $\$ 1.47$ per ton of product sold or 30.5 percent of total annual environmental costs. Only 3 of 22 dealers reporting indicated that additional full- or part-time employees were hired as a direct result of environmental improvements or regulatory requirements.

Maintenance and repair cost for environmental structures is defined as the cost of materials used to repair these structures. Maintenance and repair costs totaled $\$ 78,038$ and were reported by 16 dealers. The average cost was equal to $\$ 0.34$ per ton or 7.1 percent of total annual environmental costs. 


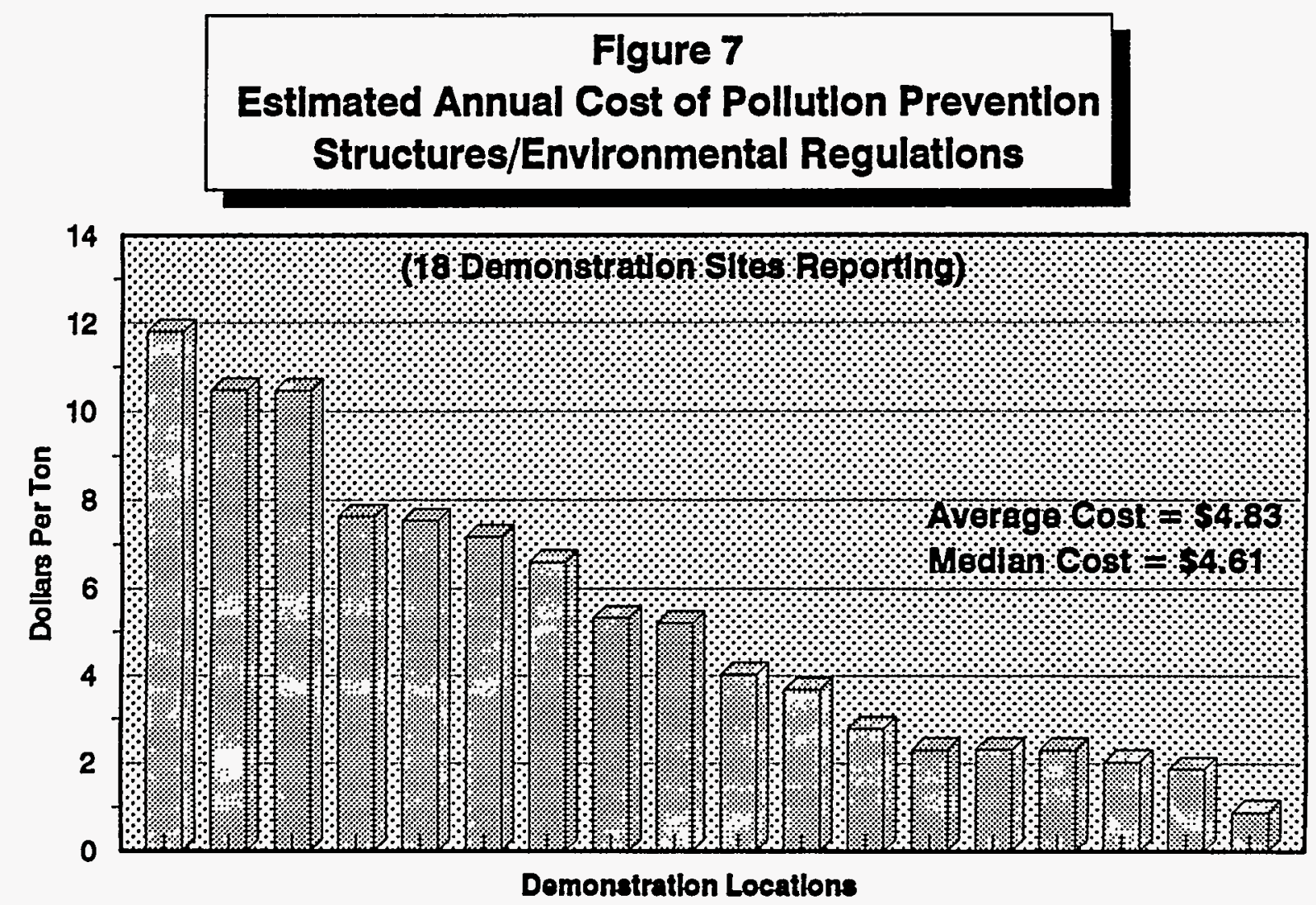


A portion of total insurance costs can usually be allocated as an environmental cost. Environmental insurance costs were reported by 17 dealers and totaled $\$ 83,548$--an average cost of $\$ 0.37$ per ton of product sold or 7.6 percent of annual environmental costs.

Annual depreciation cost associated with pollution prevention structures was the largest single expense item, as was expected, and totaled $\$ 395,294$. Depreciation costs were reported by all 18 demonstrators. The average depreciation cost was $\$ 1.75$ per ton of product sold or 36.2 percent of the total annual environmental costs.

General office/business/miscellaneous expense is a "catch all" category. The expenses reported in this category include such items as interest expense, office supplies, postage, contractual costs, legal expenses, ground or water sampling, site improvement costs, and any other expense incurred as a result of environmental investments or regulations. These expenses totaled $\$ 203,412$ and were reported by 17 demonstrators. The average cost was $\$ 0.90$ per ton of product sold or 18.6 percent of the total environmental expenses.

\section{Estimation of Annual Environmental Costs}

\section{Using an Economic Engineering Approach}

The survey indicated that only 3 of the 27 demonstrators who responded had actually estimated the annual cost pollution prevention structures prior to installation at their facilities. Thus, it is apparent that a methodology for estimating annual environmental costs, based on the level of investment, would be useful to agrichemical dealers for planning purposes prior to the actual investment.

To estimate the annual per-ton cost of pollution prevention structures and practices relating to environmental regulations, the agribusiness manager must first estimate the annual fixed and variable costs associated with the investment(s). Annual fixed costs include: depreciation, maintenance and repair, taxes and insurance, and interest. Variable costs include: salaries, wages, and other miscellaneous environmental expenses.

Depreciation costs can be calculated using the straight-line or any other method desired. Total investment in pollution prevention structures for the survey respondents totaled $\$ 4,940,070$ or $\$ 182,965$ per plant. If it is assumed that there is no salvage value and that there is a 15-year life of the asset, the annual depreciation (calculated by the straight-line method) would be $\$ 12,198$.

Interest cost on the $\$ 182,965$ environmental investment, if financed at 10 percent for 3.0 years, would be $\$ 12,585$ per year. Interest costs should be calculated regardless of whether the investment capital is to be borrowed or is to come from company reserves. 
The survey indicated (as reported by 19 demonstration dealers) that annual maintenance and repair costs associated with pollution prevention structures averaged $\$ 2,861$ for years $1-3 ; \$ 4,451$ for years $4-6$; and $\$ 7,003$ for years $7-10$. These levels of expenditures equal $1.4,2.4$, and 3.6 percent of the initial investment cost for the three respective time periods. On average, the annual maintenance and repair cost is equal to 2.5 percent of the initial investment in environmental structures. Therefore, the estimated maintenance and repair costs associated with the $\$ 182,965$ environmental investment would be $\$ 4,574$ per year. The annual cost of taxes and insurance averaged 2.2 percent of initial investment, as reported by the 19 demonstration dealers. Therefore, the estimated annual tax and insurance cost associated with the $\$ 182,965$ environmental investment would be $\$ 4,025$.

The coefficients for both maintenance and repairs and taxes and insurance are lower than had been estimated for retail fertilizer facilities in the past (Foster and Simpson, "Estimated Ownership and Operating Costs for Selected Types of Retail Fertilizer Facilities-in Update"). However, previous coefficients included costs for all the plant and equipment. The coefficients listed above are generally for concrete structures; therefore, one would expect costs to be lower. Also, using the "average" coefficients to estimate annual costs for maintenance and repairs and taxes and insurance tends to overestimate actual expenses incurred during the first years and underestimate expenses in later years.

The total for annual fixed costs--the sum of depreciation, maintenance and repairs, taxes and insurance, and interest expenses--for the $\$ 182,966$ investment is estimated to be $\$ 33,382$. This is equal to $\$ 2.65$ per ton based on 12,578 tons of product sold per year.

Operating costs associated with salaries and wages, together with other miscellaneous environmental expenses, totaled $\$ 29,800$, based on responses from 18 dealers (appendix E). This is equal to about 16 percent of the initial environmental investment per location, including interest costs. It is impossible to estimate how much interest expense is contained in the $\$ 29,800$ cost above. However, for planning purposes, an operating cost of between 10 and 15 percent can be assumed and probably not be too far off base. For estimation purposes, 13 percent was used as the operating cost coefficient in this study. Therefore, the annual variable costs associated with the $\$ 182,966$ environmental investment would be equal to $\$ 23,785$ or $\$ 1.89$ per ton of product sold.

Total estimated annual costs, based on the assumptions used above, would equal \$57,167 or $\$ 4.54$ per ton of product sold. While the estimated cost, arrived at by using this economic engineering methodology, is $\$ 0.30$ below the average cost actually reported in the survey, it is still close enough to be useful as a planning tool for evaluating alternative levels of investment by management. The estimated annual costs associated with alternative levels of environmental investment are presented in appendix $F$. 


\section{Dealer Strategies for Offsetting the Cost of \\ Pollution Prevention Structures/Environmental Regulations}

With few exceptions, the investment in pollution prevention structures will increase operating costs. As a result, the investment can be termed "dry" or "passive"; that is, no increase in returns can be directly attributed to the investment in the traditional sense. There are four general methods of offsetting the additional costs that are incurred as a result of investments in pollution prevention structures. The agrichemical dealer can: (1) increase product prices, (2) increase tonnage throughput, (3) reduce costs, or (4) use a combination of strategies 1-3. However, demonstration dealers, and others making environmental investments, must realize that until all their competitors make the mandated investments, there will be no single strategy they can employ that will recover all additional environmental costs without impacting their competitive position in the market, especially with respect to price increases. In effect, the playing field is not level because of the differing cost structures.

Demonstration dealers were asked what methods they had used to attempt to offset the additional costs associated with environmental investments. About half of the demonstrators responding indicated that they had increased product prices. However, competition in the market area severely limited the magnitude of any price increase. As a result, none of the demonstrators were able to offset all additional costs by using this method. Seven demonstrators indicated that they were able to increase prices and recover an average of 40 percent of the increased environmental costs.

All of the demonstrators reporting indicated that they had made an effort to increase tonnage sold. If a positive initial margin is present, then this is a viable strategy for offsetting environmental costs. Eighty percent of the respondents reported that they had experienced increases in tons of product sold. Thirteen demonstrators reported that tonnage increases had offset about 28 percent of their increased environmental costs.

About two-thirds of the respondents reported that they had tried to reduce expenses as a means of offsetting environmental costs. In most of these cases, maintenance and repair expenses were targeted for cost reduction. Also, several dealers reported that increased plant efficiencies had reduced production and labor expenses, particularly overtime wages. However, none of the demonstrators reporting could accurately determine the percentage of environmental expenses that were actually offset.

It should be noted that the percentage of costs offset by both price increases and increased tonnages of product sold were not necessarily reported by the same demonstrators. Therefore, it would not be accurate to sum the two percentages and state that 68 percent of environmental costs are being offset by these two strategies. It would be accurate however, to say that the MSD/ITD dealers are implementing a combination of management strategies to offset environmental costs and that, conservatively speaking, these strategies are possibly offsetting 10-30 percent of annual environmental costs. 


\section{Benefits Accrued From Installation of \\ Pollution Prevention Structures}

A number of benefits, both tangible and intangible, may be realized as a result of investments in pollution prevention structures and in adopting environmentally sound operating practices. Both tangible and intangible benefits can only complement the management strategies utilized above and thus add to the percentage of environmental costs that can be offset.

\section{Tangible Benefits}

Thirty-seven percent of the dealers reporting indicated that they had experienced a decrease in product loss since pollution prevention structures and environmental operating practices were put in place. Eight dealers reported that the dollar value of this reduction averaged $\$ 3,412$ per year.

Only two demonstration dealers reported a reduction in insurance costs resulting from the installation of pollution prevention structures. Both dealers reported a cost reduction of $\$ 5,000$. While only two demonstrators have experienced decreased insurance costs thus far, the fact that these two have done so would indicate that such possibilities are there for everyone.

Seventy-five percent of the dealers reported that they had received rebates from chemical companies. Typically, these rebates are received when containment around chemical storage is constructed. Data on the rebate amounts were not collected.

Eighty percent of the dealers responding reported an increase in product sales (tonnage) since completion of pollution prevention structures. On average, 27 percent of increased sales volume was attributed to environmental site improvements and 73 percent of the increase was attributed to market factors. Again, assuming a positive initial margin, these increases in tonnage sold can be translated into higher profits.

Eighty-eight percent of the dealers reported that plant efficiency had increased as a result of environmental improvements and changes made in operational procedures. These increased efficiencies were expressed, in part, in increased productivity and were the result of improvements made in the physical layout of the plant as pollution prevention structures were installed. Also, greater employee productivity proved to be a product of cleaner and more efficiency-oriented working conditions. Increased production and employee productivity translate directly into higher profit levels.

\section{Intangible Benefits}

Intangible benefits involve public, customer, and even employee perceptions about the business unit. The installation of pollution prevention technologies and operating procedures make positive statements about the agrichemical plant, dealership 
management, and the dealer's commitment to the future. This type of "professionalism" can be readily marketed, and, in turn, can translate into increased tonnage sold and higher profits.

Positive perceptions reported:

- Seventy-four percent of the dealers responding reported that farmers/customers had a higher regard for their businesses since construction of pollution prevention structures.

- Fifty-six percent of the dealers reported that they believed the community or general public's perception of their business was more positive since environmental investments had been made.

- Six dealers who responded have received environmental awards for pollution prevention measures taken at their facilities. In total, $15 \mathrm{MSD} / \mathrm{ITD}$ dealers have received environmental awards. One MSD dealer won an additional award for pollution prevention structures and practices put in place at one of his other plant sites. He patterned environmental measures implemented there after his TVA-designed model site. These awards can be used as marketing tools by the demonstrators.

- Fifty-two percent of the dealers reported that improved customer perception of the business, as a result of environmental technologies installed or awards received, had led to an increase in product sales.

- Sixty-eight percent of the dealers reported that employee morale had increased as a result of environmental improvements and changes made in operational procedures.

- Ninety-six percent of the managers reported that their own peace-of-mind had increased as a result of environmental improvements and changes made in operational procedures.

\section{TECHNOLOGY TRANSFER ASPECTS OF THE. MSD/ITD PROGRAMS}

Technology transfer has long been an integral and successful part of TVA's outreach activities. Such activities have been based on some important beliefs about the characteristics of a successful program. These beliefs include: inter- and intra-agency coordination; working with and through local people; maintaining effective links with suppliers of support services; the demonstration method of technology introduction; onsite testing and research to encourage adoption of technologies, new or old, to fit the business situation; and selective use of incentives to promote participation. Perhaps above all else, the success of TVA outreach activities has centered on TVA's having the trust of its customers in the agrichemical industry--trust in TVA as an agency, trust in TVA technology, and trust in the TVA staff delivering the technology. The MSD/TTD 
programs incorporate all of the above characteristics and in so doing have been highly successful in transferring pollution prevention technologies and operating practices to the agrichemical industry.

There are many ways that environmental technologies can be "marketed" to the industry. However, personal contact with industry participants and "hands-on" demonstrations form the backbone of TVA's technology transfer efforts. Following is a list of key methods TVA has utilized to transfer environmental technologies to the agrichemical industry. In each instance, TVA staff serve as a clearinghouse of environmental information aimed at industry participants or the agencies and organizations that serve the participants. Using these methodologies, TVA has been able to impact a large segment of the agrichemical industry in spite of declines in program funding and staffing levels.

TVA directly influences the transfer of pollution prevention technologies by demonstrating environmental structures and improved management practices in cooperation with MSD/ITD dealers. TVA has formal pollution prevention demonstrations at $62 \mathrm{MSD} / \mathrm{TTD}$ agrichemical dealer sites in 27 states. Agricultural industries within these states accounted for over 75 percent of U.S. fertilizer and agricultural chemical consumption in 1994. Thus it becomes apparent that the MSD/ITD pollution prevention sites have been strategically located to afford relatively easy access to a large segment of the agrichemical industry.

Open houses conducted at 15 of the demonstrations were attended by over 2,600 representatives of state and local governments, agrichemical dealerships, universities, and the general public. Additionally, these demonstration dealers conducted 188 tours with five or less participants and 222 tours with more than five participants--a total estimated viewing by 2,700 active participants of the agrichemical industry, agriculture, agricultural related industries, or the state and federal agencies that serve them. The Boone, Iowa, ITD, located 15 miles from Iowa State University, reports an average of at least two tours per month through their facility, with participants including many foreign visitors. Many of these tours are arranged by the university and others by a national fertilizer trade association.

In addition to the tours and open houses, MSD/TTD dealers also receive questions by telephone or mail concerning pollution prevention structures erected and improved management practices implemented. The 27 demonstration dealers who completed the survey reported over 400 such contacts made by other agrichemical dealers. The Hillsboro, Kansas, ITD even made a video of their demonstration site especially for dealers who inquired about the facility but could not visit in person. TVA has made six pollution prevention videos that have a combined distribution of 361 nationwide.

In total, it is estimated that over 5,700 individuals have viewed or inquired about the environmental technologies demonstrated by the 27 MSD/ITD dealers who reported data, with about 3,700 of these being active participants in the agrichemical industry. It is assumed that if the same general responses were given by the other 35 TVA environmental demonstrators who did not complete the survey, it could be estimated that 
just over 8,000 agrichemical dealers have visited or received information from TVA demonstration sites. This figure represents about two-thirds of the agrichemical dealers in the United States.

The MSD/ITD pollution prevention programs also influence the dissemination of environmental technologies through TVA's networking with state environmental agencies, state agrichemical associations, and university extension staff. This networking is accomplished through collaboration in the selection and implementation of MSDs and in "train-the-trainer" programs which include the ITDs. The agencies and associations mentioned have a vested interest in seeing the agrichemical industry operate in an environmentally safe manner and in compliance with state regulations. More importantly, from TVA's standpoint, these agencies and associations have daily interactions with the agrichemical industry and therefore can effectively transfer environmental technologies to a greater segment of industry than can TVA at current staffing levels. TVA has not been able to conduct this direct state interaction since TVA's regional manager positions were eliminated in the early 1990s.

Other means of environmental technology transfer include: telephone or mail contacts with TVA staff; papers, presentations, publications, and handbooks; and TVA sponsored or cosponsored conferences, seminars, and workshops. To date, TVA staff in Muscle Shoals, Alabama, have received in excess of 2,000 telephone calls for environmental assistance and technologies from agrichemical dealers, over 300 calls from federal/state agencies, and about 100 calls from university specialists. It is highly probable that TVA's ten regional managers, eight of whom were located in field offices across the United States until summer 1993, had at least as many or more calls for environmental assistance as did the Muscle Shoals-based staff.

TVA management and staff have given over 65 presentations on environmental topics, with a combined attendance of 4,000 agrichemical dealers. TVA staff have written 11 internal TVA papers, 2 of which have had a combined distribution of 1,500 copies. At least 12 papers have been published in widely distributed trade magazines, such as Dealer Progress and Farm Chemicals, as well as Application Technology, and in newsletters, such as "Agricenter Today," as well as in several state plant food association communications. In addition, numerous non-TVA authored articles have appeared in the trade press highlighting TVA's pollution prevention program. And at least three TVAsponsored (or co-sponsored) conferences on environmental technologies have been held, with about 800 agrichemical dealers attending.

\section{SUMMARY}

Fertilizers and pesticides are a major source of surface and groundwater contamination in the United States. The agrichemical industry came under increasing pressures in the mid 1980 s to implement environmentally sound operating practices and install containment structures around fertilizer and chemical storage/handling areas to prevent contaminants 
from moving offsite into adjoining watersheds. This led to the implementation of TVA's model site and individual technology demonstration programs.

The general objectives of these programs have been to provide research, development, and application of pollution prevention technologies and strategies for industries that market or use fertilizers, pesticides, and other agricultural chemicals. To meet these objectives and aid in the transfer of environmental technologies, 62 pollution prevention research/demonstrations have been established in 27 states.

It is estimated that two-thirds of the agrichemical industry has been directly or indirectly exposed to the pollution prevention technologies demonstrated by TVA at these MSD/ITD dealer locations. Direct exposure has been accomplished through tours of the MSD/ITD sites; TVA-sponsored environmental conferences and workshops; papers, publications, and videos; telephone and mail contact with TVA staff; and personal contact with TVA staff in the field. Indirectly, the exposure has come from TVA's input into the writing of state environmental regulations.

The demonstration dealers have reported that the pollution prevention structures recommended by TVA are working to their satisfaction and that they were more than satisfied with TVA's performance as a supplier of environmental information/technology. The average annual cost of pollution prevention structures installed at demonstration sites was $\$ 4.83$ per ton of throughput. The median cost was slightly lower at $\$ 4.61$ per ton.

Benefits associated with environmental investments, as reported by the demonstration dealers, included: lower shrinkage costs, lower insurance costs, rebates from chemical companies, increased production and application efficiencies, and increased annual tonnage of product(s) sold, with the latter resulting from improved and more positive customer perception of the agribusiness unit. The end result of these benefits is increased economic value of the business site. Thus, the tangible and intangible benefits associated with investments in pollution prevention structures and improved management/operational strategies recommended by TVA partially, and in some cases completely, offset the annual cost of the environmental investment. The "close to neutral" benefit-cost ratio makes the "mandated" environmental investment by some agrichemical dealers more palatable. And there is strong indication that it may actually encourage environmental investments by agrichemical dealers in states where environmental regulations are not yet in place or where regulations are currently being considered. 


\section{SOURCES OF INFORMATION}

Foster, Thomas H., and G. Scott Simpson. "Estimated Ownership and Operating Costs for Selected Types of Retail Fertilizer Facilities-An Update." Indiana Plant Food and Agricultural Chemicals Association, Inc., Indianapolis, Indiana, January 1980.

Rylant, Karen E., and Ronald J. Williams. "Pollution Prevention for Agricultural Industries." Departmental Publication, 1994.

Simpson, G. Scott. The Impact of Investments in Environmental Containment on Retail Dealer Costs and Returns. TVA Circular Z-270, August 1990.

Williams, Ronald J., Karen E. Rylant, W. Joe Free, and Carl A. Cole. "Beyond Compliance-Pollution Prevention for Agricultural Retailers." Presented at the American Chemical Society Annual Meeting, August 23, 1994.

Williams, Ronald J., and Horace C. Mann. "Selected Demonstration and Educational Products/Activities." July 1992.

Williams, Ronald J., and Jo Ann Fowler. Technology Introduction Activities in the Field Programs Department. Departmental Publication, 1991.

Williams, Ronald J., and James M. Ransom. "The Role of Retail Fertilizer Dealers in Reducing Groundwater Contamination: A Focus on Educational Needs." Provided to Congress of the United States, Office of Technology Assessment, June 1989.

Williams, Ronald J. Model Site Demonstrations. Departmental Publication, 1993.

Williams, Ronald J. Individual Technology Demonstrations. Departmental Publication, 1993. 


\section{ACKNOWLEDGMENTS}

The author wishes to recognize: (1) the Pollution Prevention for Agrichemical Industries Team for significant contributions made in the preparation of this paper (M.C. Ambrose, W.G. Bennett, M.F. Broder, W. Buchanan, C.A. Cole, D.L. Kachelman, L.R. Tate, and E.L. Waddell); (2) J.A. Fowler, Technology Transfer Team, for information and editorial assistance provided; and (3) those demonstrators (listed on the following page) who responded to the survey or allowed me to visit their facilities to collect data. 


\section{Demonstrators/Retailers Participating in the Economic Review of Pollution Prevention Research/Demonstrations \\ at Agrichemical Retailer Sites}

Participating Demonstrator/Retailer

Agriform Farm Supply

John Pryor Company

Stone's Farm Supply

Fuller Fertilizer

West Fertilizer, Inc.

Jasper Plant Foods, Inc.

Treynor Ag

West Central Cooperative

Wynn's Ag Center, Inc.

Cooperative Grain and Supply

Delphos Co-op

Farmers Union Co-op Business Assoc.

Farmers Fertilizer Company

Ouachita Fertilizer Company, Inc.

Willard's Delmarva Ag. Service

South Central Coop

Brunswick River Terminal

Glasgow Cooperative Association

Heiman, Inc.

Service \& Supply Cooperative

Ag-Pro Coop

Bowie Fertilizer, Inc.

TriCo Farm Service

Nutrite Corporation

Convoy Equity Exchange

Cone Ag Service

Agro Tech Services
City

Woodland

Salinas

Center

Tioga

Farmer City

Jasper

Treynor

Boone

Clarinda

Hillsboro

Delphos

Saint Mary's

Bowling Green

Monroe

Lynch

Fairfax

Brunswick

Fayette

Rockville

Bell Flower

Gordon

Miller

Oxford

Waterloo

Convoy

Pierre

Lampassas
State

California

California

Colorado

Illinois

Illinois

Indiana

Iowa

Iowa

Iowa

Kansas

Kansas

Kansas

Kentucky

Louisiana

Maryland

Minnesota

Missouri

Missouri

Missouri

Missouri

Nebraska

Nebraska

Nebraska

New York

Ohio

South Dakota

Texas 
APPENDIXES 


\section{APPENDIX A}

\section{Model Site Demonstrations in the United States}

\section{Demonstrator}

Agriform Farm Supply

John Pryor Company

Western Farm Service

Ranch Fertilizer

Shields Soil Service

* Farmers Fertilizer Company

* Ouachita Fertilizer Company, Inc.

* Willard Agri-Service, Inc.

B\&W Co-op, Inc.

South Central Coop

Glasgow Cooperative Association

* TriCo Farm Service CaroVail, Inc.

- Convoy Equity Exchange

* Wilbur-Ellis Company

* Cone Ag Service

Hutson Ag Service, Inc.

McMinn Loudon Farmers Cooperative

Alliance Agronomics

* Companies receiving environmental awards.
City

$\underline{\text { State }}$

Woodland

California

Salinas

California

California

Florida

Illinois

Kentucky

Bowling Green

Louisiana

Maryland

Michigan

Minnesota

Missouri

Nebraska

New York

Ohio

Oregon

South Dakota

Tennessee

Tennessee

Virginia 


\section{APPENDIX B}

\section{Individual Technology Demonstrations in the United States}

Demonstrator

Dixie Ag

Centennial Ag Supply Company

Stone's Farm Supply

Yuma Farmers M\&M Cooperative

Milford Fertilizer Company, Inc.

Plant Food Systems

* Jasper Plant Foods, Inc.

Allison Kesley Ag

Geneva Elevator

Treynor Ag

United Suppliers

- West Central Cooperative

Hunold Storage, Inc.

- Cooperative Grain and Supply

Delphos Co-op

Farmers Union Co-op Business Assoc.

Kugler Company

Sklar Fertilizer Company, Inc.

* Myer Liquid Fertilizer Company

Willard's Delmarva Ag. Service

Schoolcraft Farm Service, Inc.

Brunswick River Terminal

$\mathrm{R} \& \mathrm{RAg}$

Ricketts Farm Supply

Salisbury Ag Center

- Service and Supply Cooperative

Blue Valley Cooperative

Farmers Co-op Company

J.R. Simplot

J.R. Simplot

J.R. Simplot

Reed and Perrine, Inc.

* Farm Chemicals, Inc. Morral Chemical

Western Farm Service

- Moyer \& Son, Inc.

Stoltzfus Crop Service

Beseda Fertilizer

Lee County Farmers Coop

- Wright Liquid Fertilizer

Lindemann Fertilizer Service

Western 66 Company

J.R. Simplot
City

State

Leighton

Kersey

Center

Yuma

Laurel

Immokalee

Jasper

Kesley

Geneva

Treynor

Pacific Junction

Boone

Montrose

Hillsboro

Delphos

Saint Mary's

Ulysses

Robeline

Mount Airy

Lynch

Schoolcraft

Brunswick

Cairo

Salisbury

Salisbury

Bell Flower

Seward

Platte Center

Bayard

Scottsbluff

Berea

Tennent

Raeford

Morral

Tangent

Souderton

Oxford

Whiteface

Giddings

Wall

Cost

Muleshoe

Torrington
Alabama

Colorado

Colorado

Colorado

Delaware

Florida

Indiana

Iowa

Iowa

Iowa

Iowa

Iowa

Iowa

Kansas

Kansas

Kansas

Kansas

Louisiana

Maryland

Maryland

Michigan

Missouri

Missouri

Missouri

Missouri

Missouri

Nebraska

Nebraska

Nebraska

Nebraska

Nebraska

New Jersey

North Carolina

Ohio

Oregon

Pennsylvania

Pennsylvania

Texas

Texas

Teras

Texas

Texas

Wyoming

- Companies receiving environmental awards. 


\section{APPENDIX C \\ Other Pollution Prevention Technology Transfer Sites in the United States}

Agrichemical Retailer

Limestone Furmers Cooperative

Colbert Furmers Cooperative

Lawhon Farm Supply

Planters Service \& Sales, Inc.

TriState Delta

Fuller Fertilizer

Ty-Walk Liquid Sales

Vigoro Industries

West Fertilizer, Inc.

Frick Services, Inc.

Bunkars Foed \& Supply, Inc.

Farm Service Coop

Great Dane Fertilizer, Inc.

J.R. Simplot

Marco's Food \& Soed

Underwood Soed \& Supply, Inc.

Wyn's Ag Center, Inc.

Furmers Grain \& Fuel

Pikes Fertilizer

Sperrow's Farm Service, Inc.

Agri-Turf, Inc.

Ada Feod \& Seed, Inc.

Brown's Agri Service

Callis-Tumer Farm Supply

Heimnn, Inc:

Ag-Pro Coop

Big Byron Agri-Services

Bowie Fertilizer, Inc.

Coop Oil Company

Emerson Fertilizer Compeny

Farmers Coop Oil Company

Hayman's Fertilizer of Holland, Inc

Kruger Feed \& Seed

Maple Valley Cooperative

McCool Fertilizer Company

Sargent Feed \& Grain

Crote, Inc.

Nutrite Corporation

Furmers Coop

Agro Tech Services

Blezinger, Inc.

Fariey Farm Store

Good Pasture, Inc.

$M-G$, Inc.

Miller-Bowie County Furmers Assoc.

Taylor Farm \& Ranch

The Furmstore

Thompson AgriPlex

Woods-Hughes Coop

Simplot Soilbuilders
City

State

Athens

Leighton

MaCrory

West Helena

Stuttgart

Tioge

Minooka

Fairview Heights

Farmer City

Wawaka

Granville

Harlan

Audubon

Suc City

Dunkerton

Underwood

Clerinda

Pawnec Rock

Girurd

Shelbyville

Hatfield

Ada

Rock Port

Paris

Rockville

Gordon

Grant

Miller

Alma

Emerson

Nebraska City

Hickman

North Bend

Leigh

McCool Junction

Surgent

Westfield

Waterioo

Columbus

Lampassas

Industry

DeLeon

Brownfield

Weimer

Texarkana

Yorktown

Idalou

Amarillo

Inez

Worland

Alabama
Alabama
Arkansas
Arkansas
Arkansas
Illinois
Illinois
Illinois
Illinois
Indiana
Iown
Iown
Iown
Iowa
Iowa
Iowa
Iowa
Kansas
Kanses
Kentucky
Massachusetts
Minnesota
Missouri
Missouri
Missouri
Nebraska
Nebraska
Nebraska
Nebraska
Nebraska
Nebraska
Nebraska
Nebraska
Nebraska
Nebraska
Nebraska
New York
Tew Yoxk
Texas
Texas
Texas
Wyoming
Texas
Texas
Texas
Texas
Texas
Texas
Tyon




\section{APPENDEX D}

\section{Annual Tonnage Sold by Type of Product at 18 Demonstration Sites}

\begin{tabular}{lcccr} 
Product & $\begin{array}{c}\text { Demonstrators } \\
\text { Reporting }\end{array}$ & $\begin{array}{c}\text { Total } \\
\text { Tonnage }\end{array}$ & $\begin{array}{c}\text { Weighted } \\
\text { Average } \\
\text { Tonnage }\end{array}$ & $\begin{array}{c}\text { Percent } \\
\text { of Total }\end{array}$ \\
\hline Dry bag & 9 & 5,376 & 299 & 2.4 \\
Dry bulk & 16 & 97,823 & 5,435 & 43.2 \\
Liquid nitrogen & 16 & 46,948 & 2,608 & 20.7 \\
Suspensions & 9 & 29,705 & 1,650 & 13.1 \\
Other fluids & 9 & 28,001 & 1,556 & 12.4 \\
Ammonia & 12 & 18,555 & 1,031 & 8.2 \\
Total tonnage & & 226,408 & 12,578 & 100.0 \\
\end{tabular}




\section{APPENDIX E \\ Estimated Annual Cost of Pollution Prevention Structures/Environmental Regulations at 18 TVA Model Site and Individual Technology Demonstrations}

\begin{tabular}{lcccr} 
Expenses & $\begin{array}{c}\text { Total } \\
\text { Annual } \\
\text { Cost }\end{array}$ & $\begin{array}{c}\text { Demonstrators } \\
\text { Reporting } \\
\text { Costs }\end{array}$ & Cost/Ton & $\begin{array}{r}\text { Percent } \\
\text { of Total } \\
\text { Cost }\end{array}$ \\
\hline Salaries and Wages (1) & $\$ 332,988$ & 18 & $\$ 1.47$ & 30.5 \\
Maintenance and Repairs (2) & $\$ 78,038$ & 16 & $\$ 0.34$ & 7.1 \\
Taxes and Insurance & $\$ 83,548$ & 17 & $\$ 0.37$ & 3.6 \\
Depreciation & $\$ 395,294$ & 18 & $\$ 1.75$ & 18.6 \\
Other Environmental Expenses (3) & $\$ 203,412$ & 17 & $\$ 0.90$ & 100.0 \\
Total Environmental Expenses & $\$ 1,093,280$ & & $\$ 4.83$ & \\
Total Tonnage Sold & & & & \\
\hline
\end{tabular}

1. Includes time spent by employees and management in: (1) repairing, maintaining, and cleaning pollution prevention structures; (2) preparing environmental reports; and (3) managing other environmentally related matters.

2. The cost of materials used in the repairs and maintenance of pollution prevention structures.

3. Other environmentally related expenses. Includes, but is not limited to, such items as: (1) interest expense associated with environmental structures, (2) office supplies or expenses incurred in the preparation of environmental reports, (3) legal expenses regarding environmental matters, (4) soil and/or water sampling costs, (5) site improvement costs, and (6) any other environmentally related costs. 


\section{APPENDIX F}

Estimated Annual Fired and Variable Costs Associated With Alternative Levels of Investment in Pollution Prevention Structures

\begin{tabular}{|c|c|c|c|c|c|c|}
\hline $\begin{array}{c}\text { Investment } \\
\text { in } \\
\text { Containment }\end{array}$ & Depreciation & $\begin{array}{c}\text { Taxes } \\
\text { and } \\
\text { Insurance }\end{array}$ & $\begin{array}{c}\text { Maintenance } \\
\text { and } \\
\text {. Repairs } \\
\end{array}$ & $\begin{array}{c}\text { Interest } \\
\text { on } \\
\text { Investment }\end{array}$ & $\begin{array}{c}\text { Variable } \\
\text { Operating } \\
\text { Costs } \\
\end{array}$ & $\begin{array}{r}\text { Annual } \\
\text { Cost } \\
\end{array}$ \\
\hline \multicolumn{7}{|c|}{ (Dollars) } \\
\hline 5,000 & 333 & 110. & 125 & 344 & 650 & 1,562 \\
\hline 10,000 & 667 & 220 & 250 & 688 & 1,300 & 3,124 \\
\hline 15,000 & 1,000 & 330 & 375 & 1,032 & 1,950 & 4,687 \\
\hline 20,000 & 1,333 & 440 & 500 & $.1,376$ & 2,600 & 6,249 \\
\hline 25,000 & 1,667 & 550 & 625 & 1,720 & 3,250 & 7,811 \\
\hline 30,000 & 2,000 & 660 & 750 & 2,063 & 3,900 & 9,373 \\
\hline 35,000 & 2,333 & 770 & 875 & 2,407 & 4,550 & 10,936 \\
\hline 40,000 & 2,667 & 880 & 1,000 & 2,751 & 5,200 & 12,498 \\
\hline 45,000 & 3,000 & 990 & 1,125 & 3,095 & 5,850 & 14,060 \\
\hline 50,000 & 3,333 & 1,100 & 1,250 & 3,439 & 6,500 & 15,622 \\
\hline $60,000^{\circ}$ & 4,000 & 1,320 & 1,500 & 4,127 & 7,800 & 18,747 \\
\hline 70,000 & 4,667 & 1,540 & 1,750 & 4,815 & 9,100 & 21,871 \\
\hline 80,000 & 5,333 & 1,760 & 2,000 & 5,503 & 10,400 & 24,996 \\
\hline 90,000 & 6,000 & 1,980 & 2,250 & 6,190 & 11,700 & 28,120 \\
\hline 100,000 & 6,667 & 2,200 & 2,500 & 6,878 & 13,000 & 31,245 \\
\hline 125,000 & 8,333 & 2,750 & 3,125 & 8,598 & 16,250 & 39,056 \\
\hline 150,000 & 10,000 & 3,300 & 3,750 & 10,317 & 19,500 & 46,867 \\
\hline 175,000 & 11,667 & 3,850 & 4,375 & 12,037 & 22,750 & 54,678 . \\
\hline $\begin{array}{l}200,000 \\
250,000\end{array}$ & $\begin{array}{l}13,333 \\
16,667\end{array}$ & $\begin{array}{l}4,400 \\
5,500\end{array}$ & $\begin{array}{l}5,000 \\
6,250\end{array}$ & $\begin{array}{l}13,756 \\
17,195\end{array}$ & $\begin{array}{l}26,000 \\
32,500\end{array}$ & $\begin{array}{l}62,490 \\
78,112\end{array}$ \\
\hline 300,000 & 20,000 & 6,600 & 7,500 & 20,634 & 39,000 & 93,734 \\
\hline 350,000 & 23,333 & 7,700 & 8,750 & 24,074 & 45,500 & 109,357 \\
\hline 400,000 & 26,667 & 8,800 & 10,000 & 27,513 & 52,000 & 124,979 \\
\hline 450,000 & 30,000 & 9,900 & 11,250 & 30,952 & 58,500 & 140,602 \\
\hline 500,000 & 33,333 & 11,000 & 12,500 & 34,391 & 65,000 & 156,224 \\
\hline
\end{tabular}

Inputs for Calculation of Annual Costs:

Depreciable Life Years 